\title{
GLOBALIZATION, PARTY POSITIONS, AND THE MEDIAN VOTER
}

\author{
By HUGH WARD, LAWRENCE EZROW, and HAN DORUSSEN*
}

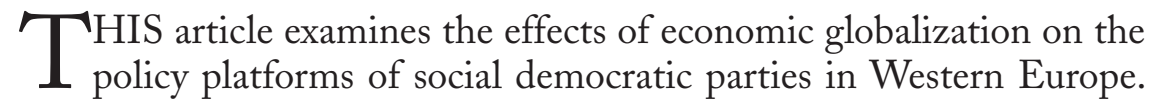
Some leading social democrats have suggested that globalization constrains their policy options. U.K. Labor Party Chancellor Gordon Brown stated, for instance, in his Mansion House speech on June 21, 2006:

But in my view no advanced industrial economy facing global competition can either shelter their old industries or services, nor can they neglect the big, serious, and long-term challenges that arise from this new phase of globalization: the challenge of resisting all forms of protectionism and instead breaking down the barriers to an open trading global economy; the challenge of moving Europe from its days as a trade bloc-inward looking and unreformed-to global Europe, outward looking, competitive, reforming and with a modern social dimension. ${ }^{1}$

Even more dramatically, the antiglobalization movement sees power leaking from weaker states to institutions articulating the interests of global capital, such as the International Monetary Fund (IMF) and the World Bank. ${ }^{2}$ It identifies multinational firms, financial corporations, and elites in newly industrializing countries like China and India as the winners from globalization and the poor in the South as well as the unskilled working class and lower-middle-class workers in the richer North as the losers. These latter groups together with the trade unions and public sector workers are traditionally viewed as the key constituencies of social democratic parties. ${ }^{3}$ In order to maintain their electoral base, when in power social democratic parties promote policies that favor these interests, including Keynesian demand management to ensure low unemployment, industrial policies to promote economic

\footnotetext{
*We would like to acknowledge the valuable comments on earlier drafts of this paper made by Jim Adams, Jay Dow, Tim Hellwig, Vera Troeger, and Andrew Whitford. We also thank Spyros Kosmidis for research assistance.

${ }^{1}$ Guardian 2006.

${ }^{2}$ Green and Griffith 2002.

${ }^{3}$ For partisan theories of electoral politics in particular, see Hibbs 1987.
}

World Politics 63, no. 3 (July 2011), 509-47

Copyright (C) 2011 Trustees of Princeton University doi: $10.1017 / \mathrm{S} 004388711100013 \mathrm{X}$ 
growth, redistributive taxation, extensive welfare provisions, and a large public sector. Arguably globalization calls this pattern into question ${ }^{4}$ and generates constraints that force center-left parties to converge on the positions of the center right for two reasons. First, because capital is increasingly globally networked, ${ }^{5}$ if the left doesn't converge capital will tend to relocate where tax rates and social costs of production are lower, labor markets are less regulated, and counterinflationary policy and balanced budgets are a higher priority. Second, because financial markets have been deregulated, ${ }^{6}$ unless the left converges, speculative investors who dislike government policy can pose the threat of currency crises linked to movement of capital out of the national currency.

The literature suggests that the effects of globalization are actually conditional on a number of institutional factors and choices made by governments. Our contribution is to explicitly model the way the impact of globalization is mediated by domestic party competition. We argue that the position of the median voter determines the effects of economic globalization on social democratic parties. Theories that emphasize links between parties and their core support groups (partisan theories) can be overly simplistic because social democratic parties typically have to compromise on core principles to make themselves more appealing to middle-class voters in the political center ground. If the median voter is expected to be far enough to the right, social democratic party positions will not be constrained by globalization. Their policies will be sufficiently business friendly anyway because of the need to reflect the preferences of the electorate. However, social democratic parties are likely to be under pressure to shift their policies to the right when facing the combination of a globalized national economy and a left-leaning electorate.

Our theoretical argument adapts Donald Wittman's ${ }^{7}$ formal model of party competition, which assumes parties maximize expected utility given uncertainty about the distribution of the electorate. We add a perceptual globalization constraint, which may or may not be effective depending on the expected position of the median. If the median is far enough to the left, the constraint is effective and the party moves to the right fearing severe electoral costs; but if the median is far enough to the right, the constraint does not affect the party's position. The model further helps us to understand possible second-order effects on parties

\footnotetext{
${ }^{4}$ E.g., Cox 1993, 260-62; Cerny 1990, 204-32.

${ }^{5}$ Held et al. 1999, 236-82.

${ }^{6}$ Held et al. 1999, 189-35.

${ }^{7}$ Wittman 1983.
} 
of the right when social democratic parties are constrained. We predict that the parties of the right will move to the right, but to a lesser extent than without an effective constraint.

The formal model also demonstrates that unless empirical studies include an interaction between measures of globalization and the position of the median voter, they are misspecified. Dennis Quinn and A. Maria Toyoda ${ }^{8}$ show that voter and party ideology are important to an explanation of the international diffusion of financial market deregulation. Their study calls attention to the risk of omitted variable bias when domestic factors are ignored. ${ }^{9}$ We report empirical evidence from fifteen West European countries between 1973 and 2002 that supports the conclusion that the effects of globalization are indeed contingent on the position of the median voter. The main dependent variable is party position derived from analysis of manifesto data. ${ }^{10}$ To date, most of the empirical literature on globalization has focused on measures of policy. Since this article is primarily concerned with party competition, policy pledges of parties are arguably the appropriate empirical focus. Moreover, these policy pledges tend to affect policy in the long run. ${ }^{11}$ We find that interaction terms between measures of globalization and the median are significant, with the expected sign both in models of general left-right position and in models of policy on the welfare state. We also report results on taxation levels that suggest pressures on parties' policy pledges do feed through to some policy outputs.

\section{Globalization, Pledges, and Policies}

A key question in the debate on globalization is whether one of its effects is to undermine the welfare states that developed in nearly all advanced industrial economies after the end of the Second World War. In the earliest phase of the debate scholars often came to pessimistic conclusions. For example Dani Rodrik ${ }^{12}$ argues that while globalization results in an increased demand for compensation through the welfare state, it also reduces the ability of governments to perform that role

\footnotetext{
${ }^{8}$ Quinn and Toyoda 2008.

${ }^{9}$ Studies in which the dependent variable is a measure of public policy, such as business taxation, often include the proportion of time the left has been in power interacted with indicators of globalization, e.g., Hays 2003. However, the second-order prediction of our model also suggests the inclusion of an interaction between the proportion of time the right has been in power and indicators of globalization.

${ }^{10}$ Budge et al. 2001.

${ }^{11}$ McDonald and Budge 2005. Admittedly, the way such pledges affect policy is complex, because governments also respond to organized interests and pressures from the international system.

${ }^{12}$ Rodrik 1997.
} 
effectively. Eventually governments can no longer finance the required income transfers because companies that pay significant amounts of corporate taxes become footloose and relatively unconcerned with social cohesion. Even though he does not predict a "race to the bottom" in all forms of regulation of business, Fritz Scharpf expects globalization to result in a reduction of taxes on profits and downward pressure on social regulation and labor standards. ${ }^{13}$ Torben Iversen and Thomas Cusack argue that apparent effects of globalization are actually due to deindustrialization linked to technical change. ${ }^{14}$

It has become more common to see the effects as contingent on institutional variation. Geoffrey Garrett argues that macroeconomic success is possible in coherent systems in which the left dominates politically, unions organize a high percentage of the labor force, and national wage deals struck in corporatist bargaining can be made to stick. ${ }^{15}$ The left's core constituency will demand compensation for the economic insecurity resulting from globalization. He finds that coherent left systems are willing and able to meet these demands since corporatist national wage bargaining prevents erosion of productivity gains from investment and protects the competitiveness of the vital international sector. Garrett's empirical work supports the hypothesis of welfare state expansion in coherent left systems as compared to coherent right systems or those in which the left's power is more ambiguous. Carles Boix finds that once financial deregulation occurs, whether socialist parties use deficits as a macroeconomic tool is inversely related to the degree of social corporatism. ${ }^{16}$

Another theory that emphasizes the conditional nature of globalization effects is put forward by Peter Hall and David Soskice who argue that both liberal market economies (LMEs) and coordinated market economies (CMEs) are coherent varieties of capitalism and exhibit complementarities between the way the labor market and corporate systems are coordinated. ${ }^{17}$ Countries approximating the LME ideal type (such as the U.S. and the U.K.) and the CME ideal type (such as Germany and the Nordic countries) have strong potential for growth because they embody distinct forms of national comparative advantage. ${ }^{18}$ In CMEs, the relatively high degree of welfare provision and unemployment protection

\footnotetext{
${ }^{13}$ Scharpf 1998.

${ }^{14}$ Iversen and Cusack 2000.

${ }^{15}$ Garrett 1998, 80-81.

${ }^{16}$ Boix 2000.

${ }^{17}$ Hall and Soskice 2001. Iversen and Soskice 2009 argue that proportional representation may also be a complementary political institution for CMEs.

${ }^{18}$ Hall and Gingerich 2009; cf. Kenworthy 2006.
} 
encourage workers to develop firm and industry-specific skills that complement the structure of corporate coordination with its emphasis on longer-term finance and long-standing networks of implicit contracts. These complementarities support comparative advantage in incremental innovation. ${ }^{19}$ CMEs' welfare and labor-market policies are not static, but neither are they especially threatened by globalization. Indeed existing policies are often supported by business. ${ }^{20}$

The empirical literature finds evidence for modest, if any, welfare retrenchment due to globalization. ${ }^{21}$ Although the pace of welfare state expansion slowed in the 1980s, few countries experienced real decline in expenditure. Institutional path dependence strongly affects national responses to external pressures, and internal problems such as aging populations may be more significant than external ones. Brian Burgoon finds welfare policies to be conditional on which groups are adversely affected by globalization, what policies are offered to ameliorate those effects, and whether offsetting policies are opposed by powerful groups such as business. Duane Swank observes that high public-sector deficits and Anglo-Saxon domestic institutions seem to interact with high capital mobility to produce welfare state retrenchment. In addition, James Allan and Lyle Scruggs find distinct differences between left and right welfare policies for some periods and limited evidence for others. ${ }^{22}$

Similar weak and contingent effects of globalization are found for other core economic policies such as taxation, spending, macroeconomic policy, and business regulation. Swank and Sven Steinmo provide some evidence that globalization cuts statutory rates of corporate tax but not its effective rate (after allowing for state subsidies to business), and they find ambiguous evidence that globalization shifts the tax burden onto labor and consumption. Jude Hays agrees that there has not been a race to the bottom, but finds that the tax burden has shifted over time towards labor-especially in consensus democracies. Scott Basinger and Mark Hallerberg find that states react to others' attempts to attract investment by making tax cuts, but the degree to which they do so depends on the domestic veto structure and their expectations about other states' political costs for cutting taxes. Globalization may affect only countries with relatively large asset endowments

${ }^{19}$ Cf. Taylor 2009.

${ }^{20}$ Estevez-Abe, Iversen, and Soskice 2001; Hall and Soskice 2001; Pontusson forthcoming. However Venn 2009 finds a strong negative correlation across Organization of Economic Cooperation and Development countries between levels of employment protection in 1985 and changes in employment protection from 1985 to 2008, with CMEs generally subject to reductions.

${ }^{21}$ van Kersbergen 2000; Pierson 2006.

22 Burgoon 2001; Swank 2005; Allan and Scruggs 2004. 
because only they have a chance of attracting footloose capital. It may sometimes lead to de facto leveling up of business regulation because capital in developing countries wants access to markets with higher product standards. ${ }^{23}$

Different indicators of globalization suggest sometimes contradictory effects on spending. ${ }^{24}$ Some intertemporal and cross-national inconsistency could derive from the partisan mode ${ }^{25}$ that underpins much of the empirical literature on the impact of globalization. In that model parties primarily respond to the preferences of their activists and core constituencies. In contrast, in the formal spatial model outlined below, these preferences only determine on which side of the median voter parties locate. Partisan theory largely ignores the idea that parties have to respond to shifts in public opinion, an observation for which James Adams, Michael Clark, Lawrence Ezrow, and Garrett Glasgow find clear empirical evidence. ${ }^{26}$ So far, however, little attention has been given to the possible effects of globalization on public opinion and the possible indirect implications for party competition.

Ronald Rogowski's ${ }^{27}$ model considers the effects of the median voter and the structure of the domestic economy on party competition. The median voter has different preferences over policy to those of capital, but her utility is also a function of labor's share of national income. Moving policy toward capital results in increased inward investment; hence the median voter gets a bigger payoff from this other component of her utility but loses in terms of policy. Under pressure due to more mobile capital, parties converge on more business-friendly policies only if the median's policy preferences are initially close enough to those of business. In the Alicia Adserà and Boix ${ }^{28}$ model, the decision to open the economy and the decision about funding the welfare state are taken together. The median voter is assumed to belong to an industry that gains from openness only if the world economy is doing well. If it is not, she may still be attracted by a compensation package from the party favoring openness. Funding of this package depends on which industries gain from openness and by how much.

These models represent a considerable advance for the study of the effects of globalization, but differ from ours in two respects. First, they

\footnotetext{
${ }^{23}$ Swank and Steinmo 2002; Hays 2003; Basinger and Hallerberg 2004; Cai and Triesman 2005; Vogel 1995.

${ }^{24}$ Garrett and Mitchell 2001; Brady, Seeleib-Kaiser, and Beckfield 2005.

${ }^{25}$ Kitschelt 2001.

${ }^{26}$ Adams et al. 2004.

${ }^{27}$ Rogowski 2003.

${ }^{28}$ Adserà and Boix 2002.
} 
assume that parties are purely office seekers, which we find implausible in light of the evidence that left and right parties adopt distinctive policies over long periods. Party differentiation can be explained by invoking party policy goals together with uncertainty about the distribution of the electorate in a one-dimensional space. ${ }^{29}$ Second, the earlier studies focus on specific issues while we seek to explain the broad character of the party programs. Our theoretical contribution is to model the effects of globalization allowing for parties with policy goals and for uncertainty over the voter distribution. In this setup it is clear that an effective constraint moves social democratic parties to the right, but there are also nonobvious implications. Even though globalization does not constrain parties on the right, it still affects their policy platforms because, in turn, they react to what the left does. Consequently, it allows these parties to adopt positions closer to their ideal policy goals and move to the right, albeit to a lesser extent than left parties.

We also contribute to the emerging empirical literature on globalization and party competition in which it has become common to rely on data from the Comparative Manifesto Project (CMP). For example Adams, Andrea Haupt, and Heather Stoll use CMP data to estimate the impact of public opinion and globalization on party positions. They find that unlike members of other party families, left parties seem neither affected by the position of the median nor systematically affected by globalization. They explain these results using the idea that such parties are ideological, programmatic, and give much more power to their members, and therefore are less likely to be influenced by external forces. In contrast, we argue that any left responsiveness depends on the location of the median voter. ${ }^{30}$ Helen Milner and Benjamin Judkins ${ }^{31}$ use measures of party attitude toward trade openness and government intervention derived from the CMP to test whether the left and right's positions have converged as a consequence of globalization. They find that globalization has reduced differences in position conditional on institutional factors. However, they do not control for the position of the median. Stephen Nelson and Christopher Way ${ }^{32}$ recode CMP data to define a dummy for large rightward shifts in the position of left parties and then estimate hazard-rate models of such turning points. They

\footnotetext{
${ }^{29}$ Budge et al. 2001; Calvert 1985; Duggan and Fey 2005.

${ }^{30}$ Adams, Haupt, and Stoll 2009. Some care is needed when comparing our study with Adams, Haupt, and Stoll's since there are slight differences in the empirical setup of the studies. Adams et al. 2004 focuses on nine countries for the period 1976-98.

${ }^{31}$ Milner and Judkins 2004.

${ }^{32}$ Nelson and Way 2007.
} 
find no evidence that shifts in the position of the median matter, but increased portfolio investment-one indicator of globalization-seems to reduce the hazard rate. Again this study does not allow for the possibility that the impact of globalization is conditional on the position of the median. Jonas Pontusson and David Rueda ${ }^{33}$ also use CMP data and, to our knowledge, theirs is the only other study that conditions party response to the position of the median voter. They show that parties of the left respond to increasing inequality if voter turnout is high enough. They argue that the core constituencies of left parties can counteract pressure to move to the center. Like them, we assume that parties have policy goals they are willing to trade against higher chances of winning.

\section{A Formal Model of Party Competition under Globalization}

Parties are assumed to maximize expected policy payoffs. Globalization affects these because it impacts on parties' perceived chances of holding office. We assume that social democratic politicians believe they cannot win elections if they adopt policies that are too far to the left given their nation's location in the global economy because such policies would lack credibility. There are various possible scenarios in which the electorate might anticipate policy U-turns. Policies that are unpopular with the business community could make businesses reluctant to invest domestically. If policies lead to large deficits, they may have to be reversed because of bond market demand for a high-risk premium or because higher domestic interest rates squeeze consumption and investment. In extremis, they might be reversed under bailout terms by international institutions like the IMF. Loss of confidence in foreign-exchange markets can lead to policy reversal as a fixed exchange rate comes under pressure. Attempts to keep interest rates low may have to be reversed because low interest rates lead to outflow of speculative capital.

The critical factor for party competition is not whether any of these scenarios actually eventuate, but whether politicians believe their policies are credible to the median voter. The effects of globalization are complex and highly contingent because different groups of voters and businessmen respond to specific policies in various ways that are difficult to predict. Thinking in terms of whether a particular left-right position is credible given the level of globalization is procedurally rational

\footnotetext{
${ }^{33}$ Pontusson and Rueda 2010.
} 
for parties and cuts through complexities. ${ }^{34} \mathrm{~A}$ number of specific policy packages may be consistent with a given left-right position and details can to some extent be worked out midterm. Meanwhile having a credible left-right pitch is important because it is procedurally rational for voters to think in those terms. ${ }^{35}$

Accordingly, our assumption is that the median voter prefers center-right party B if center-left party A's policies lack credibility. The assumption holds even if party A's policies are closer to the median voter's ideal policy position-i.e., the median voter would have preferred A's policies had they been credible. In other words, the median voter fears a possible crisis more than the implementation of party B's proposals. We show that losing the election is worse for party A than locating at the constraint. ${ }^{36}$

In formal terms, parties $\mathrm{A}$ and $\mathrm{B}$ compete along a single issue dimension. Party A's position is denoted by a, and party B's position by b. The parties are uncertain about the position of the median voter, $\mathrm{m}$, but share the same cumulative distribution function for this random variable, $\mathrm{F}(\mathrm{m})$, with probability density function $\mathrm{f}(\mathrm{m})$. Assuming proximity voting or that voters vote for the party nearest to their position, then for $\mathrm{a} \leq \mathrm{b}$, the probability that $\mathrm{A}$ wins the election is $\mathrm{F}((\mathrm{a}+\mathrm{b}) / 2)$ : those to the left of $(a+b) / 2$ vote for $A$. The expression gives the probability that the median is in this group and hence a majority vote for A. If $a \leq b$, the probability that $B$ wins is $1-F((a+b) / 2)$. If $a>b$, the probability that $A$ wins is $1-F((a+b) / 2)$ and the probability that $B$ wins is $F((a+b) / 2)$.) To make the analysis as tractable as possible we assume specifically that the distribution function is logistic, with mean $\mu$ and shape parameter s, so:

$$
\mathrm{F}((\mathrm{a}+\mathrm{b}) / 2)=1 /\left(1+\mathrm{e}^{-\mathrm{x}}\right)=\mathrm{F}(\mathrm{x})
$$

where

$$
\mathrm{x}=((\mathrm{a}+\mathrm{b}) / 2-\mu) / \mathrm{s})
$$

and

$$
f(x)=e^{-x} /\left(1+e^{-x}\right)^{2} .
$$

Note that the variance of the logistic distribution is $\pi^{2} s^{2} / 3$. In the equation below, further assumptions are that party I's utility declines linearly

${ }^{34}$ Simon 1985.

${ }^{35}$ Downs 1957.

${ }^{36}$ Possibly a more realistic assumption is that costs to party A's electoral chances taper in gradually as it moves further and further to the left of the constraint, but a model incorporating this idea gives essentially the same picture as the one we present. 
with distance from its policy ideal point, which is also denoted by I; so parties are assumed to be risk neutral. Without loss of generality, we assume that $\mathrm{A}<\mathrm{B}$. Parties aim to maximize their expected payoff from policy over one electoral round. For instance for $A$ this is measured by the probability that A wins times A's utility from implementing its policy plus the probability that B wins times A's utility from B's policy. ${ }^{37}$ Hence for a given position of $\mathrm{J}, \mathrm{j}, \mathrm{I}$ aims to maximize:

$$
U_{I}(i, j)=-|i-I| G(x)-|j-I|(1-G(x))
$$

with respect to $i$, where

$$
\mathrm{G}(\mathrm{x})=\mathrm{F}(\mathrm{x}) \text { for } \mathrm{i} \leq \mathrm{j} \text { and }(1-\mathrm{F}(\mathrm{x})) \text { for } \mathrm{i}>\mathrm{j} .
$$

Similarly, the expected policy outcome is given by

$$
o(i, j)=i G(x)+j(1-G(x)) \text {, }
$$

so that it is a convex combination of the positions taken by the parties such that

$$
\mathrm{i}<\mathrm{o}(\mathrm{i}, \mathrm{j})<\mathrm{j} \text {, where } \mathrm{i}<\mathrm{j} \text {. }
$$

To establish a baseline, suppose that there is no constraint on the position parties adopt. Given the outcome is a convex combination, it is easy to see that positions $a^{*}$ and $b^{*}$ form a Nash equilibrium of the game only if $\mathrm{A} \leq \mathrm{a}^{*}<\mathrm{b}^{*} \leq \mathrm{B}$. If not, at least one party can get a better outcome by moving in the direction of its ideal point, given that for $\mathrm{i}<\mathrm{j}$, $o(i, j) \in(i, j)$ and for $i=j, o(i, j)=i=j$.

We assume that $\mathrm{A}<\mu<\mathrm{B}$ and, more specifically, that $\mathrm{A}<\mu-2 \mathrm{~s}$ and $\mathrm{B}>\mu+2 \mathrm{~s}$. The first assumption is plausible if it is accepted that the social democratic party's core constituency is the (organized) working classes and the public sector, as often assumed in the debate on the effects of globalization. Similarly, it is reasonable in this context to assume $\mu<\mathrm{B}$. Because $s$ is an increasing function of the variance of the distribution over the position of the median voter, the specific assumption amounts to the assertion that the standard deviation of the median is relatively low compared to the distance between parties' policy ideal points. With modern opinion polling, this seems plausible. In online Appendix $1,{ }^{38}$ which contains technicalities concerning equilibria of the model, we show that if there is no constraint on the parties there

\footnotetext{
${ }^{37}$ Our conclusions are not substantially altered if we add a component of utility due to rents from winning office; see Wittman 1983.

${ }^{38}$ Online appendices are available from the authors at http://privatewww.essex.ac.uk/ ezrow/.
} 
is a unique Nash equilibrium at $a^{*}=\mu-2 s$ and $b^{*}=\mu+2 s .{ }^{39}$ For the unconstrained case, we denote A's and B's best-response functions as $R_{A}(b)$ and $R_{B}(a)$ respectively.

Suppose there is a constraint at $c, \mu-2 s<c<\mu+2$ s, so that the constraint is effective on $\mathrm{A}$, but not on $\mathrm{B}$. For $\mathrm{a}<\mathrm{c}$ and $\mathrm{b} \geq \mathrm{c}$, assume $\mathrm{A}$ always loses the election, whereas for $\mathrm{a}=\mathrm{c}$ and $\mathrm{b} \geq \mathrm{c}$, assume $\mathrm{A}$ has a strictly positive probability of winning. Then if $a<c, b^{*}=B$, because $B$ can win at its policy ideal point for sure. Then for any $\mathrm{a}<\mathrm{c}$,

$$
\mathrm{U}_{\mathrm{A}}(\mathrm{a}, \mathrm{B})<\mathrm{U}_{\mathrm{A}}\left(\mathrm{c}, \mathrm{R}_{\mathrm{B}}(\mathrm{c})\right) \text {, }
$$

because the outcome from the strategies $\{\mathrm{a}, \mathrm{B}\}$ is $\mathrm{B}$, whereas the outcome from $\left\{c, R_{B}(c)\right\}$ is to the left of $B$ and to the right of $c$, since $R_{B}(c)$ $\leq \mathrm{B}$. Thus $\mathrm{A}$ is better off locating at the constraint than anywhere to the left of it and the constrained equilibrium is $\left(a^{* \prime}, b^{* \prime}\right)=\left(c, R_{B}(c)\right)$. The technical details are in online Appendix 1, but the intuition is easily grasped from Figure 1.

In Figure $1, R_{A}(b)$ and $R_{B}(a)$ show how each party would respond to the other's position in order to maximize its utility if unconstrained. These functions intersect once at the unconstrained Nash equilibrium $(\mu-2 s, \mu+2 s)$. If the constraint is imposed, $A$ is never better off locating to the left of $c$ than at $c$. If it locates at $c, B$ 's response is $R_{B}(c)$. If $B$ locates there, we show that A's best response is c: A moves as far as possible to the left without violating the constraint. Under the constraint the corner solution $\left(c, R_{B}(c)\right)$ is the unique Nash equilibrium. The arrows indicate the way that A's equilibrium position moves as a consequence of the constraint. Notice $B \geq R_{B}(c)>\mu+2$ s, i.e., the knock-on effect of the constraint is that $\mathrm{B}$ moves toward its policy ideal. The intuition is that at $(c, \mu+2 s) B$ gets a better outcome if $A$ wins than it would have got at $(\mu-2 s, \mu+2 s)$ in the unconstrained case. $B$ trades some of this advantage in by moving nearer its policy ideal. For relatively small shifts of this sort, B's chances of winning decline only slightly while it significantly improves its payoff if it wins and implements its policy. B moves to the right, but because of the slope of the reaction function, it does not move as much as $\mathrm{A}$.

Figure 2 summarizes the various possibilities. In the first scenarioas shown in Figure 2(a) - with a relatively right median voter, any globalization constraint would be ineffective. Since the equilibrium positions of the parties are both to the right of the constraint, globalization has no impact on either party's policy platform. When the constraint

${ }^{39}$ Cf. Brams and Merrill 1983. 


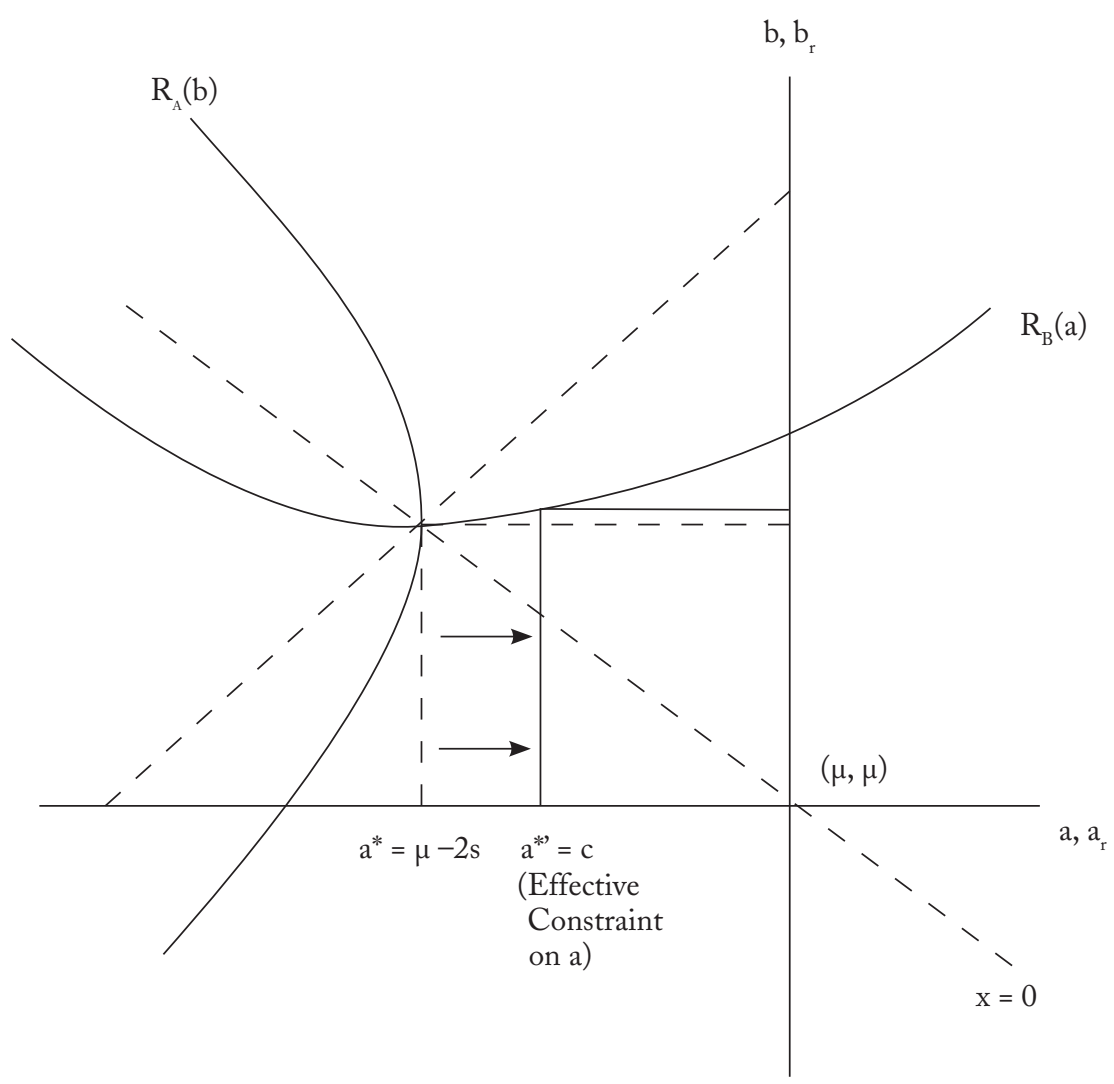

FIGURE 1

Unconstrained and Constrained Equilibria of Two-party

Competition

is effective, both parties are predicted to move to the right compared to the unconstrained case (see Figure $2(\mathrm{~b})$ ), though B will not move as much as $\mathrm{A}$. Whether a given constraint is effective depends on the expected position of the median voter and the degree of uncertainty over this position.

Many of the systems we wish to apply our results to are not effective two-party ones and they do not have competition between wellestablished center left and center right coalitions. In a Wittman-style model Adams and Samuel Merrill ${ }^{40}$ show that in a first-past-the-post system three-party equilibriums are divergent and symmetric around the expected position of the median, with the center party located at

${ }^{40}$ Adams and Merrill 2006. 


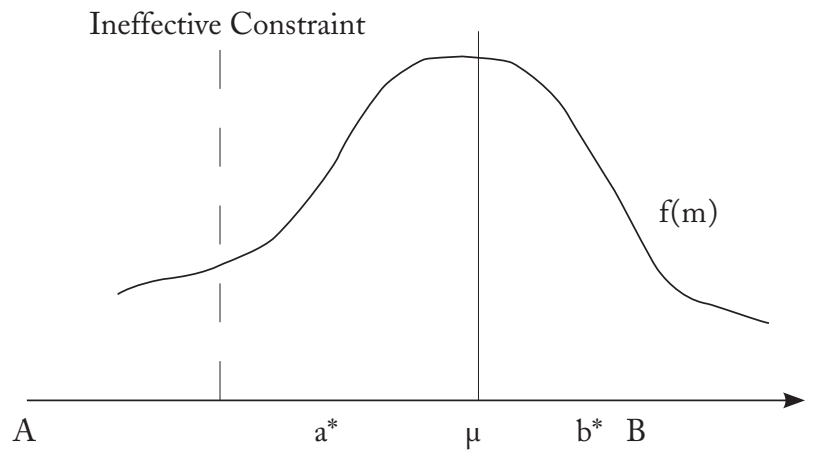

(a)

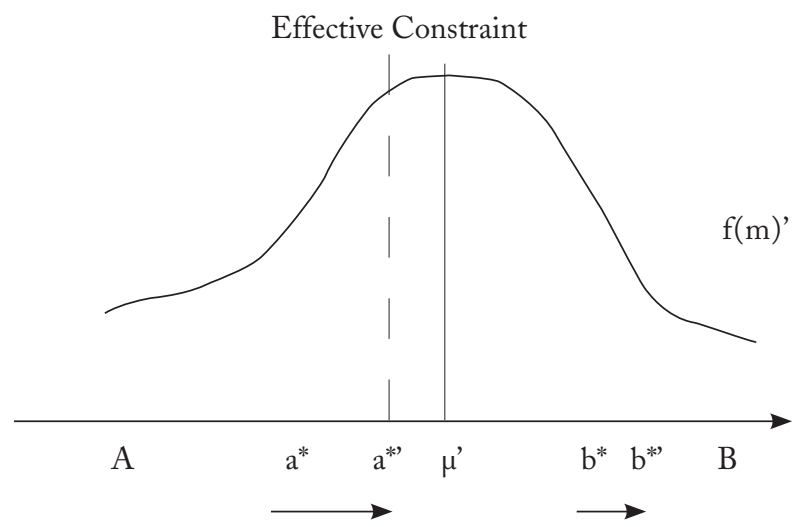

(b)

FIGURE 2

Equilibrium Positions with Ineffective and Effective Constraints

that position. Allowing for coalitions and strategic voting, computations suggest that if they exist, equilibriums in three-party competition over a single dimension are divergent. ${ }^{41}$ In addition, recent results on multiparty competition where voters' utility functions reflect partisan biases as well as party positions have divergent equilibriums and parties moving in consort to the left or right. ${ }^{42}$ Accordingly, we conjecture that in three-party Wittman-style models and models incorporating valence, the impact of imposing a constraint on the left-if the constraint is effective-would be similar to that in our model.

${ }^{41}$ Roemer 2001, 281-96.

${ }^{42}$ Adams, Merrill, and Grofman 2005, 52-70. 
If a country is more exposed to global economic forces, it seems reasonable to assume that the globalization constraint will be further to the right. The constraint arises partly as a result of the threat to withdraw capital investment or through short-term speculative flows moving out of the economy. ${ }^{43}$ The larger a nation's exposure, the greater the consequences if the threat were carried out. This in turn will lead to larger electoral costs for any party that is deemed by the electorate to have brought about this effect, and more pressure will exist for it to conform to market views about policy. Specifically, this pressure will generally be in a rightward direction if a party is directly subject to the constraint. Hence we test the following hypotheses, allowing for the interaction between the positions of the constraint and the median:

- H1. The greater the degree to which an economy is exposed to economic globalization, the further to the right political parties in that system will locate.

$-\mathrm{H} 2$. The further to the right the median voter is expected to be, the further to the right political parties will locate.

Moreover,

-H3.The further to the right the median voter is expected to be, the lower the rightward impact of economic globalization on political parties.

These hypotheses can be tested if the statistical model for party positions includes a measure of economic globalization (expected to have a positive coefficient), a measure of the median voter's expected position (which should have a positive coefficient), and a multiplicative interaction between these two variables (expected to have a negative coefficient).

From the formal model it also follows that:

-H4. The more exposed an economy is to economic globalization, the further to the right parties of both the left and the right will locate, but the impact will be greater on parties of the left.

\section{RESEARCh DEsign}

Our data set is a pool where the cases comprise political party/years for 180 parties over the period from 1973 to 2002. For reasons discussed below, we use Eurobarometer data to operationalize the position of the median voter, so we are limited to parties in countries that were member

\footnotetext{
${ }^{43}$ Rogowski 2003.
} 
states of the European Union by $2002 .{ }^{44}$ Because member states entered the EU at various times, we do not have relevant information on voter position for all parties for all years. The parties included are those for which information is available from the CMP and covers all parties that held seats in the legislature in each relevant country/year. ${ }^{45}$ The countries included in the analysis are Austria, Belgium, Denmark, Finland, France, Germany, Great Britain, Greece, Ireland, Italy, Luxembourg, the Netherlands, Portugal, Spain, and Sweden.

\section{The Dependent Variable}

CMP data allows us to map party positions over the entire time period and for all of the countries. CMP estimates should be reliable and accurate statements about party positions at the time of elections because they are often the result of intense intraparty debates. These measures are generally consistent with those from other party-positioning studies, such as those based upon expert placements, citizen perceptions of parties' positions, and parliamentary voting analyses, which provide additional confidence in the longitudinal and cross-national reliability of the estimates. ${ }^{46}$

The methods used to map CMP-data-only party policy positions are described and debated at length elsewhere, but deserve a brief review. ${ }^{47}$ Policy positions are characterized by the quantitative examination of party stances on policies on the basis of content analysis of election programs. ${ }^{48}$ Individual coders isolate quasi-sentences in a party's policy program and pair them with policy categories (e.g., education, defense, law and order, and morality) using a preestablished common classification scheme. The classification scheme is made up of fifty-six categories and the percentages of each category provide the basis for estimating the policy priorities of a party. The left-right ideological scores for parties' policy programs, position, range from -100 (extreme left) to +100 (extreme right). Using relevant questions from the CMP, we extend our approach to statements on welfare policy as part of our robustness tests.

\footnotetext{
${ }^{44}$ Schmitt and Scholz 2005.

${ }^{45}$ Budge et al. 2001; Klingemann et al. 2006.

${ }^{46}$ See Hearl 2001; McDonald and Mendes 2001; cf. Laver, Benoit, and Garry 2003.

${ }^{47}$ For a more thorough description of the coding process, see Budge et al. 2001, Appendix 2. Debate exists over which approach (e.g., expert opinions, citizen perceptions, or codings of manifestos) is the most accurate for measuring party policy positions. Indeed a special issue of Electoral Studies is dedicated to analyzing the trade-offs that accompany each of these approaches. Marks 2007; see also Benoit and Laver 2006, chap. 3: 88-122. We rely on CMP data because the data set covers a longer time period than the alternatives.

${ }^{48}$ Budge et al. 2001.
} 


\section{The Main Independent Variables}

In this section, we discuss key independent variables, median voter position, and economic globalization. We concentrate on questions of measurement and explore the issue of the possible endogeneity of these variables in a subsequent section. The longitudinal measure of the median voter position is based on public opinion and derives from Eurobarometer surveys dating from 1973, the first year that the leftright self-placement item appears on the Eurobarometer survey, until 2002. The surveys ask approximately 2,000 respondents in each country to place themselves on a $1-10$ left-right ideological scale. ${ }^{49}$ The mean of respondents' self-placements, voter_position, is our measure of the expected position of the median, which is appropriate since the distribution of self-placement is typically unimodal and relatively symmetric. $^{50}$

The correlations between the various indicators used in the literature for economic globalization are generally quite high, which is conducive to constructing an index. Such an index is also helpful to avoid problems with multicollinearity. While Axel Dreher constructs separate indices of economic, social, and political globalization that he then combines into an overall index, ${ }^{51}$ we are most interested in his economic index, economic_globalization. In it the underlying indicators are a country's trade flows, portfolio and direct investment, tariff and invisible barriers to trade, and capital controls. After normalizing the indicators, the weights assigned to them are derived from first principal component analysis, so that the index captures as much of the variation in the indicators as possible. ${ }^{52}$

\footnotetext{
${ }^{49}$ Specifically, the Eurobarometer surveys ask, "In political matters, people talk of 'the left' and 'the right.' How would you place your views on this scale?" Empirical analyses suggest that with the exception of Belgium, Germany, and Ireland, Eurobarometer respondents' left-right self-placements are comparable cross-nationally (i.e., respondents' self-placements are meaningfully related to the preferences along specific dimensions of policy debate); Huber 1989. We re-estimated the parameters of the basic model specification excluding Belgium, Germany, and Ireland. These parameter estimates, available from the authors upon request, strengthened support of our substantive conclusions.

${ }^{50} \mathrm{In}$ our data set, the correlation over country years between voter position and a measure making a median correction for grouped data is $0.969(\mathrm{n}=100)$. The results using this measure are similar to those reported here and are available from the authors.

${ }^{51}$ An early attempt at index construction is the Kearney/Foreign Policy Globalization Index, but the weightings of the factors entering the index are arbitrarily chosen and potentially inferior to weightings chosen so that the overall index captures as much of the information in its components as possible. Kearney and Foreign Policy 2006; Lockwood 2004, 515; Heshmati 2006; Dreher 2006.

${ }^{52}$ When constructing their globalization index, Warwick University's Center for the Study of Globalization 2008 controls for such structural factors as a country's size and geographical location, statistically stripping out structural effects so as to focus on nations' policies toward globalization; Lockwood 2004, 511-12. This is not appropriate for our purposes because we are interested in the impact of both past policy and a country's fixed characteristics on the current policies of its political parties.
} 


\section{An Econometric Analysis of the Conditional Effects of Globalization and Voter Position on Party Policy Platforms}

Regression 1 in Table 1 tests the third hypothesis that the impact of globalization on party platforms is conditional on the expected position of the median voter. It includes both economic_globalization and voter_position (for which the theory suggests positive coefficients) and their interaction, voter_positionXecon_glob (with an expected negative coefficient). Before turning to the substance of the results, we consider some issues regarding estimation.

The models have a lagged dependent variable and are estimated using fixed effects. Hence, preoposition is the party's position on the leftright scale at the previous election. ${ }^{53}$ The regressions include the lagged dependent variable because party adjustment to electoral and economic forces is not likely to be immediate, so dynamics are of interest. It is appropriate to include fixed effects because of the need to eliminate bias due to the effect of unmeasured variables that are not strictly exogenous, i.e., not uncorrelated with other explanatory variables for all time periods. ${ }^{54}$ For example, we cannot control for party policy goals because we lack a plausible proxy measure for them. Although they might be expected to be relatively stable, they could correlate with the expected position of the median because they may change with the views of a party's core support groups (which might also affect the median).

While fixed effects should help avoid problems with estimates of the impact of the median, the inclusion of the lagged dependent variable generates problems with the fixed-effects estimator. Besides losing information on between variation, carrying out the fixed-effects transformation in a model with lagged dependent variables induces a correlation between the (transformed) lagged dependent variable and the (transformed) error terms. Thus the fixed-effects estimates are biased. Nathanial Beck and Jonathan Katz discuss the advisability of using alternative estimators for lagged dependent variable models. Their Monte Carlo simulations suggest that the Anderson-Hsiao IV

${ }^{53}$ To preserve degrees of freedom, we use CMP scores for years prior to 1973 (the first year we use for the remainder of our data) when calculating prevposition. The substantive conclusions are unchanged when we omit this variable from the model specification.

${ }^{54}$ We reject the use of the random-effects estimator because we do not believe the necessary strict endogeneity assumption that justifies its use is satisfied and because we are mainly interested in the impact of globalization, which is not time invariant or even slow changing and which would be a problem under fixed effects; Wooldridge 2006, 497. The use of a Hausman test to help decide whether to use the fixed-or random-effects estimator is inappropriate here because the presence of the lagged dependent variable in the model means neither estimator is consistent under the null that the errors are uncorrelated with all other independent variables. 
TABLE 1

Globalization and Party Position: Alternative Measures of Globalization

\begin{tabular}{|c|c|c|c|c|c|}
\hline \multirow[b]{2}{*}{ Dependent Variable } & \multicolumn{5}{|c|}{ Regression } \\
\hline & $\begin{array}{c}\text { (1) } \\
\text { Position }\end{array}$ & $\begin{array}{c}(2) \\
\text { Position }\end{array}$ & $\begin{array}{c}\text { (3) } \\
\text { Position }\end{array}$ & $\begin{array}{c}\text { (4) } \\
\text { Position }\end{array}$ & $\begin{array}{c}\text { (5) } \\
\text { Position }\end{array}$ \\
\hline prevposition & $\begin{array}{c}.176 \\
(3.57)^{* * * *}\end{array}$ & $\begin{array}{c}.179 \\
(3.34)^{* * * *}\end{array}$ & $\begin{array}{c}.188 \\
(3.84)^{* * * *}\end{array}$ & $\begin{array}{c}.172 \\
(3.32)^{* * * *}\end{array}$ & $\begin{array}{c}.163 \\
(3.58)^{* * * *}\end{array}$ \\
\hline voter_position & $\begin{array}{l}27.2 \\
(2.91)^{* * * *}\end{array}$ & & $\begin{array}{c}9.48 \\
(1.74)^{*}\end{array}$ & $\begin{array}{c}4.57 \\
(1.42)\end{array}$ & $\begin{array}{l}35.9 \\
(2.90)^{* * * *}\end{array}$ \\
\hline economic_globalization & $\begin{array}{l}1.78 \\
(2.68)^{* * * *}\end{array}$ & $\begin{array}{c}.0951 \\
(1.44)\end{array}$ & & & \\
\hline voter_positionXecon_glob & $\begin{array}{c}-.346 \\
(2.71)^{* * * *}\end{array}$ & & & & \\
\hline totaltrade & & & $\begin{array}{r}.422 \\
(1.57)\end{array}$ & & \\
\hline totaltradeXvoter_position & & & $\begin{array}{c}-.0939 \\
(1.67)^{*}\end{array}$ & & \\
\hline fdi & & & & $\begin{array}{l}2.41 \\
(2.07)^{* *}\end{array}$ & \\
\hline fdiXvoter_position & & & & $\begin{array}{l}-.476 \\
(2.08)^{* * *}\end{array}$ & \\
\hline quinn_all & & & & & $\begin{array}{l}15.8 \\
(2.75)^{* * * *}\end{array}$ \\
\hline quinn_allXvoter_position & & & & & $\begin{array}{l}-3.03 \\
(2.81)^{* * * *}\end{array}$ \\
\hline constant & -141 & -8.86 & -45.3 & -25.1 & -190 \\
\hline Observations & 617 & 790 & 617 & 566 & 617 \\
\hline Number of parties & 138 & 146 & 138 & 131 & 138 \\
\hline R-squared (overall) & 0.45 & 0.44 & 0.43 & 0.47 & 0.38 \\
\hline
\end{tabular}

Robust, clustered t-statistics are in parentheses; ${ }^{* * *} p \leq .01 ;{ }^{* *} p \leq .05 ;{ }^{*} p \leq .10$, two-tailed tests

estimator generally performs worse on mean squared errors than estimating the fixed-effects model under ordinary least squares. We follow their advice: if there are twenty or more time periods, as in our data, it is best to ignore the inconsistency problem. ${ }^{55}$

The first difference transformation is an alternative for eliminating unobserved effects. Adams, Haupt, and Stoll ${ }^{56}$ use this transformation to help address problems of autocorrelation and they also include the differenced lagged dependent variable. However, in the presence of a

${ }^{55}$ Beck and Katz 2004, 15. They also discuss the Kiviet estimator, but our panel is unbalanced and so this could not be used.

${ }^{56}$ Adams, Haupt, and Stoll 2009; cf. Haupt 2010. 
lagged dependent variable, differencing is likely to have substantially more bias than the fixed-effects estimator. ${ }^{57}$ Unless otherwise stated, we use the fixed-effects estimator with robust clustered standard errors $^{58}$ because it is generally advisable to allow both heteroskedasticity and possible contemporaneous correlation across errors in cross sections. ${ }^{59}$

Returning to the substance of Table 1 , regression 1 , the estimates support the theoretical predictions. The coefficient on economic_globalization is positive (in support of H1), the coefficient on voter_position is also positive (in line with $\mathrm{H} 2$ ), and the coefficient on the interaction term voter_positionXecon_glob is negative (as $\mathrm{H} 3$ expects). ${ }^{60}$ Figure 3 shows the estimated coefficient on economic_globalization (with a 95 percent confidence interval) conditional on the value of voter_position. Interpreting the results presented in Table 1 , regression 1 , the effect of globalization is highest when voter_position is at its minimum value of 4.31. A shift from the minimum value of economic globalization (46.35) to its maximum value (96.68) is expected to move a party 14.6 units. In light of the standard deviation of this variable, 21.5, this is a substantively large effect. Figure 3 shows that the coefficient on economic globalization is positive and significantly different from zero only when the electorate holds left political preferences. Indeed, for values of voter_position greater than about 5.7, the results suggest that as economic_globalization increases parties actually shift significantly to the left.

Hypothesis 4 suggests that globalization has a greater impact on parties of the left than on parties on the right. The dummy left takes on the value 1 for parties coded as belonging to social democratic or communist families as classified by the CMP. After reestimating the core model and including two- and three-way interactions between left, voter_position, and economic_globalization, Figure 4 plots coefficients on economic_globalization for the range of values of voter_position for parties of the left and parties of the right. For parties of the left, the picture is similar to that of Figure 3: only if voter_position is relatively far to the left (around 4.8) are parties of the left pushed significantly to the right. For other parties economic_globalization does not have a significant effect on any value of voter_position, although as predicted

${ }^{57}$ Wooldridge 2006, 492.

${ }^{58}$ If robust errors seem advisable in estimations using panel data with fixed effects, it is best to cluster on the cross-sectional variable; Stock and Watson 2006. There was, however, little difference to the results.

${ }^{59}$ Beck and Katz 2004, 4.

${ }^{60}$ Lagging economic globalization makes little difference. Results available from authors. 


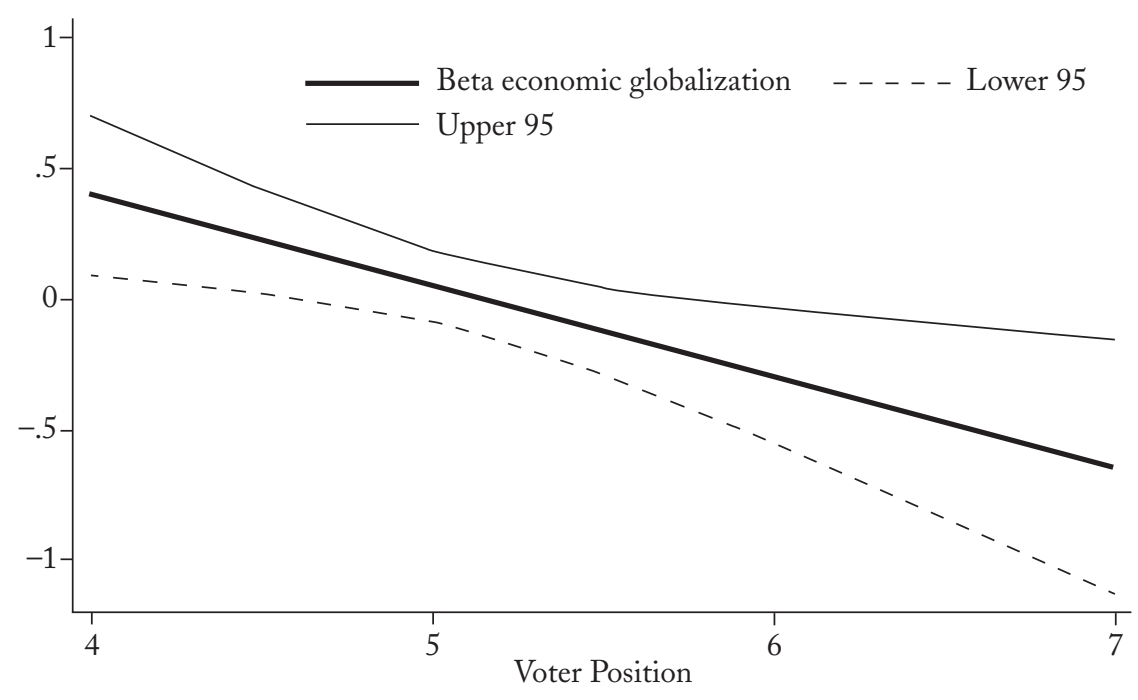

Figure 3

The Effect of Economic Globalization on Position, Conditional on Voter Position.

the central estimate of its effect declines as voter_position increases. Consistent with Hypothesis 4, the effects of economic globalization are indeed more marked for parties of the left, conditional on the median's position. ${ }^{61}$

Much of the debate on globalization has focused on Scandinavia and the social democratic left there. Perhaps counterintuitively, these are not the parties that our model identifies as most likely to be affected. Although the Scandinavian countries are relatively open, their median voters are relatively centrist compared with our data's grand mean of 5.48 (Denmark 5.59, Finland 5.78, and Sweden 5.31). Italy (4.81) and Spain (4.67), however, have the combination of relatively open economies with left-wing electorates. For these southern European cases, we predict globalization will generate significant pressures on the left. To illustrate, we consider the Spanish national election of 2000, the most recent for which the CMP provides data. The most significant party on

${ }^{61}$ We have reestimated the parameters of the basic model specification stratifying observations based on party family. Although we lose (many) degrees of freedom when we estimate the parameters for these models, the estimates are in the expected direction across families, with the exception of green parties. Results available from the authors. 


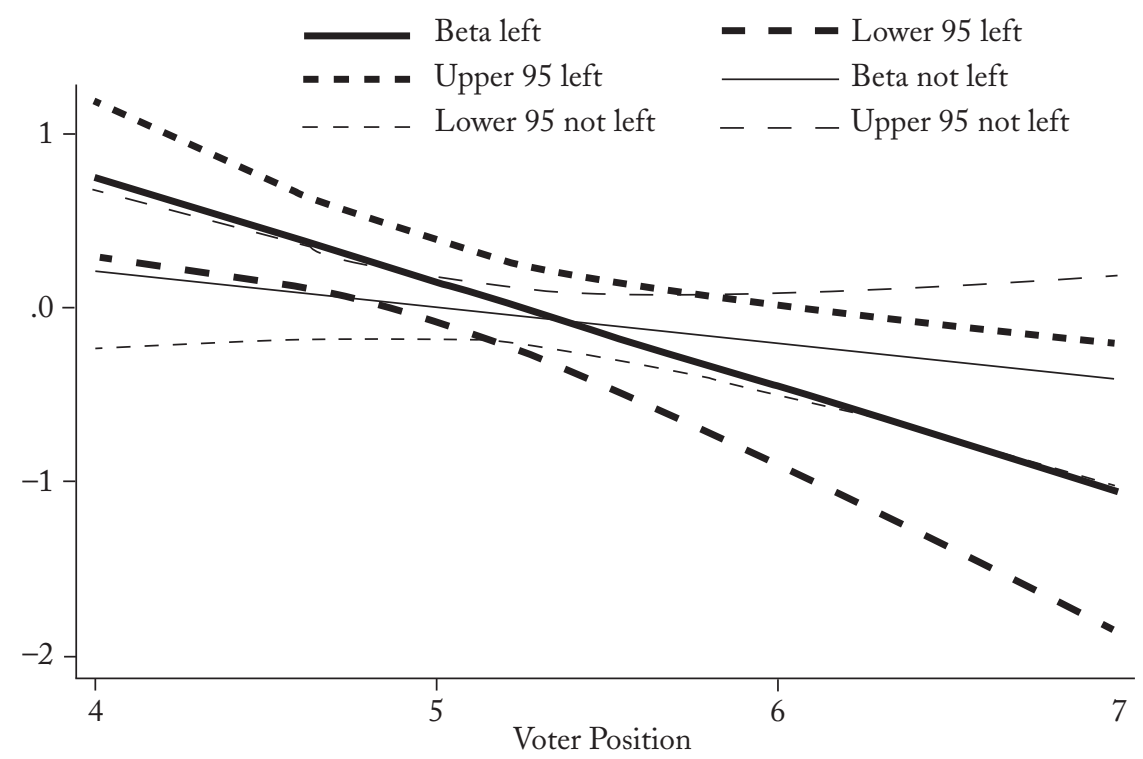

FIGURE 4

The Effect of Economic Globalization on Position, Conditional on Voter Position, for Parties of the Left AND FOR OTHER PARTIES.

Fixed effects; robust clustered $\mathrm{t}$-statistics in parenthesis, $\mathrm{n}=617$

The underlying model is:

position $_{\mathrm{t}}=-145+.17$ prevposition $_{\mathrm{t}}+22.3$ voter_position $_{\mathrm{t}}+1.05$ economic_globalization

-209 voter_positionXecon_glob +2.06 leftXecon_glob +14.2 leftXvoter_position

-.382 leftXvoter_positionXecon_glob ${ }_{\mathrm{t}}+\varepsilon_{\mathrm{t}}$

the left in Spain is the Spanish Socialist Workers' Party (PSOE), which has governed since the 2004 election. The CMP registers the PSOE in 2000 far to the left (-20.49), which is extreme when compared to parties of the left across all of the countries in the data (-14.16). That same year Spain's voter_position is also relatively far to the left at 4.86 and its economy is highly globalized (83.97 compared to 73.9 for the average of the all countries) with an annual rate of increase of 2.05 
points on the globalization index. Based on the model specification underlying Figure 4, the prediction is that the PSOE will be pushed to the right at an annual rate of around 0.47 points. On the surface, this seems like only a modest change, but if continued through the rest of the decade, such a push would have turned the PSOE from a relatively extreme member of the left family to a moderate one. We note here that tracing the process of party-position shifts requires detailed case studies beyond the scope of this paper. $^{62}$

As argued in the introduction, models that do not include the position of the median and its interaction with economic globalization are likely to be misspecified. To highlight this observation, regression 2 (Table 1) excludes voter_position and the interaction term voter_positionXecon_glob. Economic_globalization now has a positive coefficient but it is insignificant even at the 90 percent level. The second model thus underestimates ${ }^{63}$ the effect of globalization when the median voter is located to the left and fails to capture the way the effect of globalization is conditional on what the median voter wants.

A relevant issue is whether dimensions of economic globalization relating to trade flows, financial flows, and restrictions on financial flows have similar effects to those reported in regression 1 . In Table 1 , regression 3, totaltrade is a measure of imports plus exports as reported by the World Bank Development Indicators; in regression 4, fdi is inward and outward foreign direct investment also reported by the World Bank; and in regression 5, quinn_all is Quinn's measure of all restrictions on international financial flows based on IMF country reports on exchange restrictions. ${ }^{64}$ In each case the globalization measures have the expected positive sign and their interactions with voter position are negative. David Brady and Ryan Denniston show that results on the effects of globalization on manufacturing are quite sensitive to how globalization is measured. Our results do not seem that sensitive, although the effects of trade are less significant than those of investment and financial flows. ${ }^{65}$

\footnotetext{
${ }^{62}$ The PSOE administration in Spain is currently under considerable pressure to retrench. According to the Financial Times (May 12, 2010), Psoe Prime Minister Jose Luis Rodriguez Zapatero "had no choice but to undergo the welfare-state equivalent of trial by ordeal," cutting civil service pay by 5 percent and public spending by an additional 1.5 percent of gross domestic product.

${ }^{63}$ In Table 1, regression 2, when economic_globalization varies from its minimum to maximum value, parties move 4.79 units to the right.

${ }^{64}$ Quinn and Toyoda 2008.

${ }^{65}$ Brady and Denniston 2006. Quinn's measure of restrictions on financial flows gives results similar to Dreher's (2006) index economic_restrictions, with which it has a bivariate correlation of around $0.7(n=645)$.
} 


\section{Robustness Checks}

We test the robustness of Table 1's results to address possible concerns about endogeneity and causal structure, limitations on the country sample, and the error structure.

\section{Causal Pathways and Endogeneity}

When estimating models of party position, there is a possibility that globalization and voter positions are endogenous. In the Adserà and Boix mode ${ }^{66}$ the openness of the economy is endogenous to party competition because governments respond to the median's views on trade and the welfare state. Some social democratic politicians attempt to persuade the median voter that there is no alternative to restructuring the public sector in a globalized world, as illustrated by Brown's Mansion House speech quoted above. In the online appendix we reestimate regression 1 using a two-stage least squares regression (2SLS) estimator for panel data with instrumental variables (IV). We instrumented economic_globalization and voter_position. The results are consistent with those in the text, allowing for loss of efficiency when employing instruments and for loss of degrees of freedom due to the construction of instruments.

If globalization moves the median voter to the left-reflecting the desire for compensation ${ }^{67}$ - the results of regression 1 would not fully capture the impact of globalization. Under this scenario, we would capture the causal pathway whereby the constraint pushes parties to the right, but would not capture the effects on party position due to globalization pushing the median to the left. On the other hand, if voters believe that certain social democratic policies are infeasible, they may cease to find them desirable and move to the right, although this would be an example of sour-grapes thinking outside the mainstream of rational choice.

Theoretically, we do not think our results depend on the validity of the compensation thesis. We model policy pledges instead of policy implementation. Demand for compensation from organized interests may well present problems for policy implementation. Even if globalization does influence some voter preferences, it does not follow that it will necessarily affect party competition. If globalization opens up markets in the South for relatively capital-intensive products from the North while the North imports more labor-intensive products from

${ }^{66}$ Adserà and Boix 2002.

${ }^{67}$ Rodrik 1997; Garrett 1998. 
the South, the Stolper-Samuelson theorem implies unskilled labor in rich, developed economies will lose relative to capital. Thus the groups at risk are quite likely to be among the unskilled working classes located to the left of the median. If this is so, globalization might shift social democratic parties' core support group to the left while leaving the median unchanged. Suppose core support groups influence party policy preferences. Our model suggests that their position determines which side of the expected median the parties locate, not how far from it they locate; so any impact globalization has on social democratic parties' core support should not affect our results. Using individual-level survey data, Hellwig ${ }^{68}$ shows that globalization tends to reduce the level of responsibility for good economic performance ascribed by the electorate to government. Even if globalization causes unemployment and insecurity among some groups, this finding might suggest that the median would not necessarily respond by moving to the left and demanding compensatory policies.

Fortunately, it is possible to address these considerations empirically. In modeling the median's preferences we control for the possible influence of globalization. We also allow for the possible influence of governing parties on the median. ${ }^{69}$ To allow for potential endogeneity we estimate the model using 2sLS/IV. We do not find any significant evidence for a causal pathway from economic globalization to party positions via the median.

\section{SAMPLE LimitaTions}

A limitation of our study imposed by requirements for data on the position of the median voter is that it is confined to EU member states. EU membership constrains the range of positions that parties adopt on issues where the EU has competency. ${ }^{70}$ However, reduction in range does not imply pressure to move to the right; it would be implausible to claim that EU pressure is in this direction for all member states and all issues. Nevertheless it might still be argued that our findings are driven not so much by globalization as by intra-EU trade. We calculate total trade with other EU member states as a proportion of gross domestic product, EU_open; it has only a moderate positive correlation with economic_globalization $(0.12, \mathrm{n}=906)$. In web Appendix 2 we show that

\footnotetext{
${ }^{68}$ Hellwig 2001 and forthcoming.

${ }^{69}$ We obtained similar results for this average weighted by seat share in the government and for the average position of all parties in the legislature.

${ }^{70}$ Dorussen and Nanou 2006; Nanou 2009.
} 
EU_open and its multiplicative interaction with voter_position are not significant when added to regression 1 . The coefficients and confidence intervals for other variables are stable. While we need to be cautious about the external validity of our results beyond the EU context, this indicates they are likely to hold up. ${ }^{71}$

\section{Lag Structure and Autocorrelation}

In the data set, we use cross sections corresponding to years. For many parties however, in a given year there are no observations on their positions because no election was held. Indeed there is very little variance in some cross sections. ${ }^{72}$ One consequence of this data structure is that the preoposition variable does not refer to position a fixed number of years ago (as it does in standard lagged dependent variable specifications), but rather to position at the last election (where time since the last election varies across cases). In results reported in online Appendix 2 we allow for the possibility that this affects the coefficient on prevposition. As expected, we find this coefficient attenuates with time since the last election. Because this makes little difference to the substance of our results, we generally use the simpler specification, as in regression 1.

Another issue around dynamics is that the residuals from regression 1 show evidence of autocorrelation. Although including the lagged dependent variable is implicit in any response to problems of autocorrelation in the residuals, it appears not to eliminate the problem here. ${ }^{73}$ Results reported in web Appendix 2 reestimate regression 1 allowing for an AR(1) process in the residuals by using the Prais-Winsten transformation. The substantive results remain unchanged. Other models reported in this article are estimated without the correction. Another method for dealing with autocorrelation and trending in variables is to difference them, as advocated by Adams, Haupt, and Stoll. ${ }^{74}$ In online Appendix 2 we estimate a model similar to regression 1, but with the variables differenced. The results are qualitatively similar to those in regression 1: increases in globalization generate changes in party position but the effects are mediated by shifts by the median to the right.

${ }^{71}$ We could have included more cases, such as cases outside the EU, by using the Kim and Fording 2003 measure of mean voter position based on CMP estimates of party positions and their known vote shares. We use CMP data to estimate party positions and believe there is a potential circularity when using a proxy for a variable on the right-hand side of the equation that is also based on the same party-positions data.

72 This is another reason we did not use random-effects estimators.

${ }^{73}$ Beck and Katz 2004.

${ }^{74}$ Adams, Haupt, and Stoll 2009. 


\section{PARTy System EFFects ${ }^{75}$}

Iversen and Soskice's analysis ${ }^{76}$ suggests that the effects we are examining may be contingent on whether a nation has a proportional electoral system (PR). Focusing on class coalitions they deduce that in PR systems the middle classes are more likely to ally with the poor, leading to a greater emphasis on redistribution. This suggests that on the one hand, the (conditional) effects of globalization should be smaller in PR systems because they exhibit more path dependency in maintaining redistribution. On the other hand, in non-PR systems like Great Britain where the middle class is more likely to ally with the rich, globalization should have a greater effect. Thus far our empirical analyses do not control for electoral-system effects because controlling for fixed effects removes both the impact of the electoral system and that of associated forms of institutional path dependence around the welfare state. Nevertheless, we go some way toward modelling them explicitly.

In Table 2 we reestimate our model and stratify the sample into proportional (regression 6) and disproportional (regression 7) systems. France, Great Britain, Greece, and Spain are coded as disproportional. In both subsamples the coefficient on the interaction is negative. It is not significant in disproportional systems, but this may well be due to loss of degrees of freedom when the sample is split. We note that the estimate for PR systems (-.30) is less than half of the estimate for disproportional systems (-.69), which suggests that the effect we predict is more important in disproportional systems.

Because electoral systems influence the number of parties, we address the issue by stratifying by number of effective parties. To calculate the number of effective parties we use the reciprocal of Keefer's Herfindahl index of party concentration, based on seat shares in the legislature in the country/year to which the observation belongs. The sample is split based on whether the system approximates a two-party one (effective number of parties $\leq 2.5$, regression 9) or not (regression 8). Leaving aside significance levels on the grounds that regression 9 is based on a much smaller number of observations than regression 8 , there is some evidence from comparing coefficients that the impact of globalization is greater for the pure two-party cases.

\section{Welfare State and Taxation}

Much of the globalization debate is specifically concerned with the welfare state. With the CMP database it is possible to construct the var-

\footnotetext{
${ }^{75}$ We would like to thank an anonymous reviewer for pressing us to consider these effects.
}

${ }^{76}$ Iversen and Soskice 2006. 
TABLE 2

Estimates for Different Electoral and Party Systems

\begin{tabular}{lcccc}
\hline \hline & \multicolumn{4}{c}{ Regression } \\
\cline { 2 - 5 } & $(6)$ & $(7)$ & $(8)$ & $(9)$ \\
& & & Position & Position \\
& & & (Effective & (Effective \\
Dependent Variable & Position & Position & Number of & Number of \\
(Subsample) & (Proportional) & (Disproportional) & Parties $>2.5)$ & Parties $\leq 2.5)$ \\
\hline prevposition & .18 & .16 & .17 & .082 \\
& $(3.30)^{* * *}$ & $(1.34)$ & $(3.05)^{* * * *}$ & $(0.90)$ \\
voter_position & 24.4 & 47.1 & 29.1 & 72.7 \\
& $(2.19)^{* *}$ & $(1.51)$ & $(3.06)^{* * * *}$ & $(0.86)$ \\
economic_globalization & 1.52 & 3.48 & 1.85 & 5.71 \\
& $(1.93)^{*}$ & $(1.55)$ & $(2.72)^{* * * *}$ & $(0.88)$ \\
voter_positionXecon_glob & -.30 & -.69 & -.35 & -1.11 \\
& $(2.02)^{* * *}$ & $(1.49)$ & $(2.74)^{* * * *}$ & $(0.97)$ \\
constant & -127 & -243 & -153 & -371 \\
& $(2.13)^{* *}$ & $(1.62)$ & $(3.09)^{* * * *}$ & $(0.79)$ \\
Observations & 477 & 140 & 530 & 87 \\
Number of parties & 102 & 36 & 125 & 45 \\
R-squared (overall) & 0.41 & 0.49 & 0.41 & 0.09 \\
\hline
\end{tabular}

Robust clustered t-statistics are in parentheses; ${ }^{* * *} \mathrm{p} \leq .01 ;{ }^{* *} \mathrm{p} \leq .05 ;{ }^{*} \mathrm{p} \leq .10$, two-tailed tests

iable welfare, which is equal to the percentage of sentences mentioning welfare limitation minus the percentage of sentences mentioning welfare expansion. ${ }^{77}$ Notice that the higher the value of welfare, the further to the right a party's policies on this issue. The correlation between welfare and position is around $0.45(\mathrm{n}=909)$; welfare is not just a proxy for left-right position. In Table 3, regression 10, the dependent variable is welfare and we include the lagged value of welfare, prevwelfare. We expect voter_position and economic_globalization to have positive coefficients, indicating parties tend to emphasize welfare state limitation more as the median voter moves to the right and as pressures from globalization increase. We expect the coefficient on the interaction voter_positionXecon_glob to be negative, since our theory suggests if the median voter is far enough to the right globalization will not be constraining. These expectations are supported and the results are

77 The CMP defines a welfare variable that adds mentions of social justice to sentences mentioning welfare expansion. While this correlates at about $-0.8(\mathrm{n}=909)$ with our measure, we think it is better to include welfare limitation and do not think that all concern for social justice relates directly to welfare provision. 


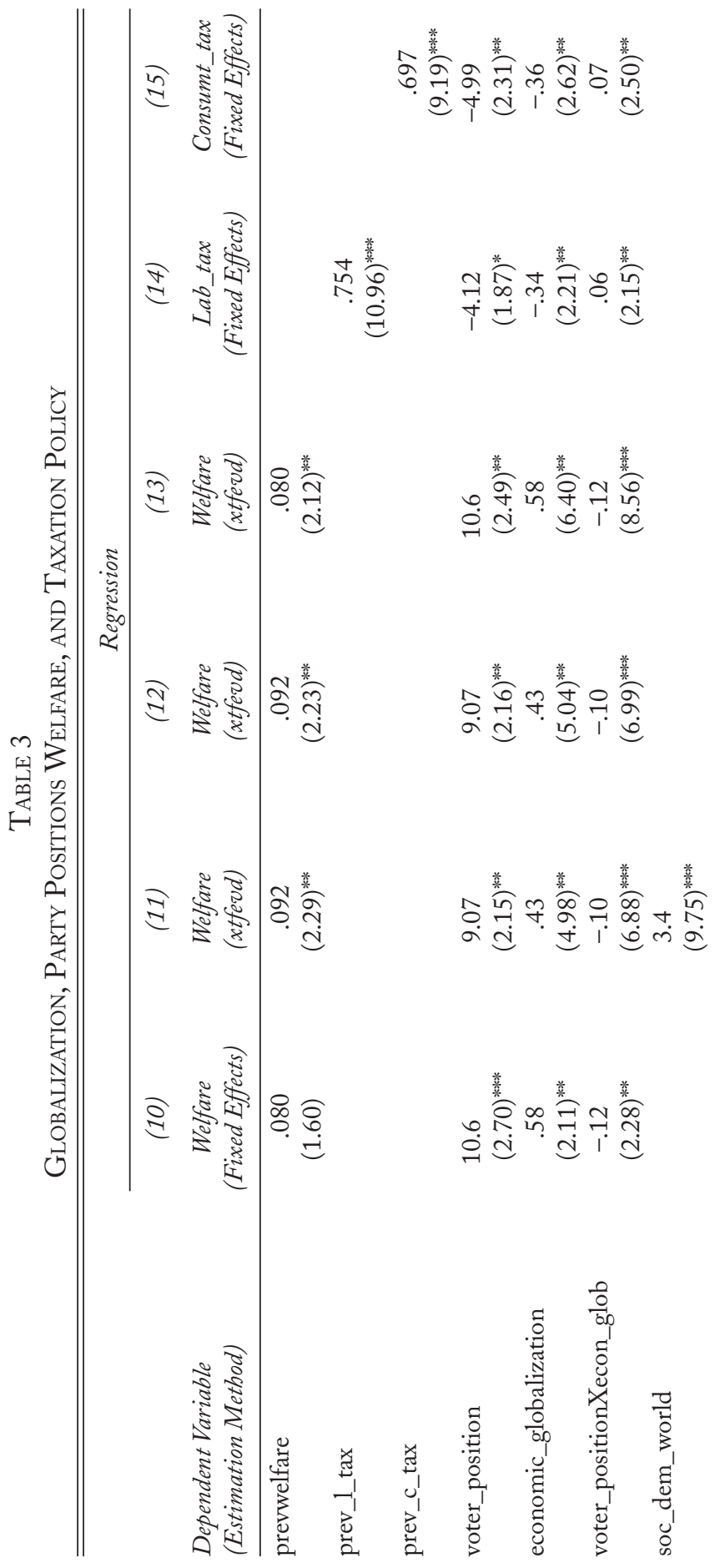




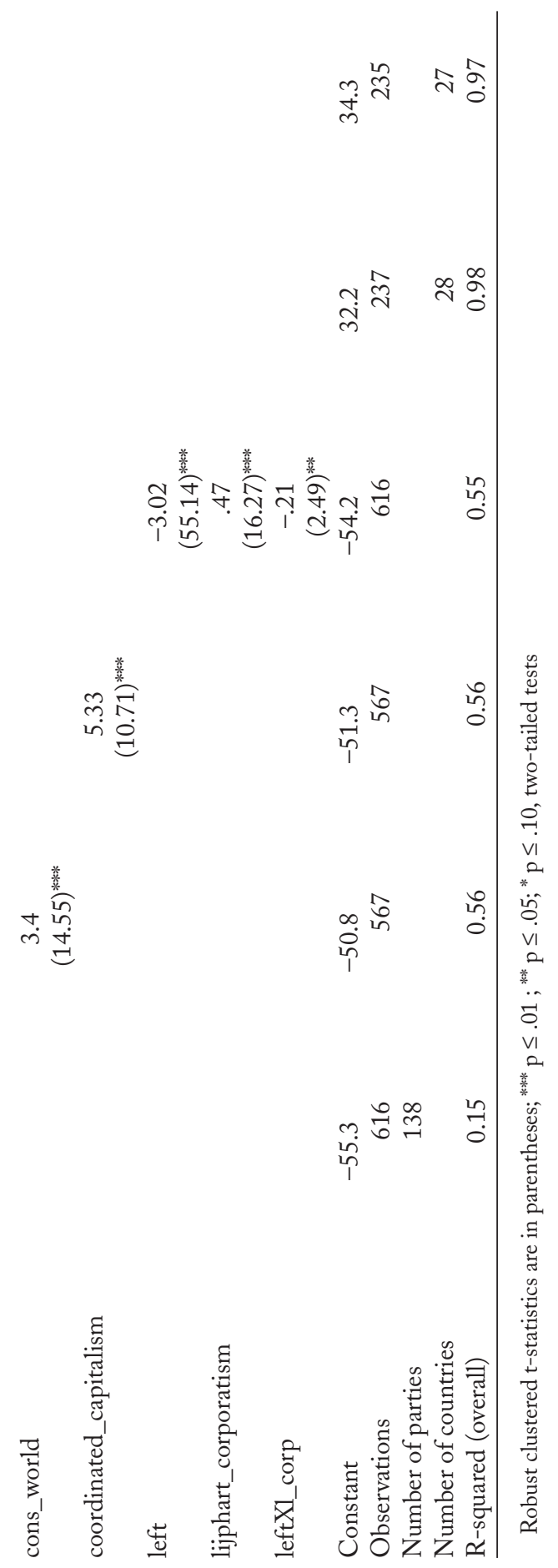


parallel to those in regression $1{ }^{78}$ Similar to the findings shown in Figure 3 , only when the median voter is relatively far to the left is the coefficient on economic_globalization positive, indicating that globalization pushes parties to advocate welfare state retrenchment under these circumstances. In this instance, though, the effect of globalization is not significant for low values of voter_position.

Gøsta Esping-Anderson characterizes welfare states as social democratic (e.g., Sweden), conservative (e.g., Germany), or liberal (e.g., the U.S. and the U.K.). Powerful parts of the business community favor the liberal model. Parties in systems with other kinds of welfare states might be expected to pick up ideas about liberal reform by diffusion on top of any constraints they are subject to due to globalization..$^{79} \mathrm{Us}^{-}$ ing Esping-Anderson's coding of types of welfare capitalism, we create dummy variables soc_dem_world, cons_world, and lib_world indicating which cluster a country belongs to. ${ }^{80}$ Inclusion of these variables allows us to further demonstrate robustness to institutional differences. Since the dummies are constant over time, their coefficients cannot be estimated using fixed effects. To address this issue, Thomas Plümper and Vera Troeger ${ }^{81}$ propose a fixed-effects vector decomposition method (referred to in Stata as "xtfevd") to estimate the impact of unchanging or slowly changing variables in a model of a panel that also includes fixed effects. We use this estimator in regression $11 .{ }^{82}$ The excluded dummy in it is lib_world. The positive coefficients on soc_dem_world and cons_world indicate additional stress on welfare state retrenchment by parties in these clusters, in line with debates on the influence of the liberal welfare state model.

According to the varieties of capitalism approach, in CMEs, parties' policies on welfare should be less subject to pressure to move to the right due to globalization. We use Hall and Daniel Gingerich's overall index of coordination, coordinated_capitalism to test this, expecting a negative coefficient. Because index values are time invariant, we use the xtfevd estimator again. As shown in regression 12, the coefficient

${ }^{78}$ The overall $\mathrm{R}^{2}$ here is lower than in regression 1 . For any given party, welfare tends to be more volatile than position, which is to be expected given that it is constructed from a much smaller number of indicators.

${ }^{79}$ Esping-Andersen 1999; cf. Brooks 2005.

${ }^{80} \mathrm{He}$ does not explicitly categorize Spain or Portugal, but from information in the text they appear to belong in the conservative cluster and are coded accordingly; Esping-Andersen 2009. For Luxembourg and Greece there was no information, so observations on these countries are dropped.

${ }^{81}$ Plümper and Troeger 2007.

${ }^{82}$ Currently xtfevd returns robust standard errors exactly 100 times greater than the correct estimate (author communication with Troeger). In Table 3 we recalculated t-values and significance levels reported by Stata to allow for this. 
is actually positive, suggesting more pressure on parties in coordinated systems. $^{83}$

Corporatism is another persistent institutional feature of some states important to the globalization debate. Following Garrett, ${ }^{84}$ we expect that the greater the degree of corporatism, the lower the impact of globalization on parties belonging to the left family. Regression 13 tests this hypothesis specifically in relation to welfare. Because the hypothesis concerns a particular party family, it includes the dummy variable left for parties belonging to the social democratic and communist party families. It also includes a measure of corporatism derived from Arendt Lijphart's measure of interest-group pluralism, lijphart_corporatism ${ }^{85}$ and the interaction between these two variables, left $X l_{\text {__corp. }}$. We use the xtfed estimator because the left dummy and the measure of corporatism are time invariant. If corporatism allows parties of the left to locate nearer their policy ideal, we would expect a significant negative coefficient on the interaction left X lijp_corp. While the idea that corporatism matters is supported in relation to welfare policy, we do not find that corporatism allowed left parties to adopt positions nearer their policy ideal on the general left-right spectrum.

The coefficients on the three key variables_-voter_position, economic globalization, and voter_positionXecon_glob - are quite stable across the three specifications in regressions 11,12 , and 13 (Table 3), indicating that the hypothesized effects are robust to controlling for the type of welfare state and variety of capitalism. These results are not necessarily inconsistent with the mixed findings for the effect of globalization on welfare spending. ${ }^{86}$ Welfare spending has been shown to be relatively stable with persistent differences between left and right parties in growth in social spending when globalization is pronounced. Due to pressure for compensation or pressure to maintain distinct labor skills, the overall impact of globalization may sometimes be an increase in welfare state provision. Changes in party platform do not necessarily translate immediately or mechanically into more austere welfare state

${ }^{83}$ Hall and Gingerich 2009, 470. Results are similar using their separate indices for coordination of corporate governance and labor relations, with positive coefficients on each variable.

${ }^{84}$ Garrett 1998.

${ }^{85}$ Lijphart 1999, 177. In technical terms we standardized and inverted Lijphart's scale. Though Lijphart clearly contrasts consensus democracies (known to score high on corporatism measures) with those based on interest-group pluralism, whether this is a valid measure of corporatism may be queried. In fact Lijphart's scale correlated reasonably highly with other indices such as Kenworthy's - at about $0.63(n=413)$; Kenworthy 2003. The advantage of using our measure is that it is available for a larger number of countries than alternatives, which often exclude Spain, Portugal, Luxembourg, and Ireland.

${ }^{86}$ Pierson 2006; Potrafke 2009; Venn 2009. 
policies because policy is affected by many other factors. For example, Eunyoung $\mathrm{Ha}^{\prime} \mathrm{s}^{87}$ work suggests that the impact of globalization on policy is conditional on veto structures - it may prove difficult for parties in office to actually implement policy pledges. In government, parties can respond to the pressures from globalization in various ways. ${ }^{88}$ They might choose to maintain rather than cut welfare state benefits but fund them by increasing forms of taxation incident on labor or by reducing government borrowing.

Taxation has also been a central concern of the empirical literature on globalization. Although the focus of this paper is on party programs, our argument would have less force if there were no traceable effect on policy. We note, however, that there are similar patterns for taxation. The European Commission has compiled data on taxation across member states (and some prospective member states) since 1995 using a unified methodology to ensure that figures are comparable. ${ }^{89}$ The EU reports annual figures for implicit tax rates on labor (lab_tax) and consumption (consmpt_tax), weighting individual taxes for their relevance to these broad categories. These figures allow us to estimate models for a twelve-year period (1995-2007) making use of all annual Eurobarometer data on voter position, including up to twenty-eight countries and years where no data on party positions is provided by the CMP. The debate on taxation is complex, as suggested in the first section of this article. We test hypotheses consistent with our model of party positions without necessarily allowing for all of these complexities and expect that: 1) globalization forces tax rates down; 2) movement to the right of the median voter forces tax rates down; and 3) the further to the right the median voter, the smaller the impact of globalization. Note that this implies negative coefficients on the first two variables and a positive coefficient on their interaction. The models include the lagged dependent variable. Cases are in country years. The parameter estimates for regression 14 (lab_ tax) and regression 15 (consumpt_tax) conform to this pattern. ${ }^{90}$ Thus there is some evidence that the pressures affecting party competition feed through to tax policy. The effects do not appear to operate in relation to all forms of taxation, but this might be expected given results in the existing literature. ${ }^{91}$ Nevertheless, the results suggest that in future

${ }^{87}$ Ha 2008.

${ }^{88}$ Adserà and Boix 2002; Hall and Thelen 2009.

${ }^{89}$ European Commission 2009.

${ }_{90}$ The high overall $\mathrm{R}^{2}$ values here result from high inertia in tax rates within countries and our inclusion of the lagged dependent variable.

${ }^{91}$ In similarly specified models of top income and corporate tax rates, the signs of the coefficients are also as predicted, but the variables fail to achieve significance. Results are available from authors on request. 
studies the effects of globalization on government policies should be seen as contingent on the position of the median.

\section{Conclusions}

This study adds to the small number of attempts to formalize the effects of globalization. The model considers parties with policy goals and uncertainty so that the median voter exerts a pull but does not lead parties to fully converge. Globalization should only affect party competition if the expected position of the median is far enough to the left, in which case it moves left parties, and to a lesser extent the right parties, in a rightward direction. Arguably the failure to recognize the importance of the interaction between globalization and the position of the median produces biased estimates of the effect of globalization. The reported empirical results support this argument over a range of model specifications. They suggest that globalization has an effect, but only if the expected median is relatively far to the left. Finally, globalization has differential effects on parties of the left and the right.

The results on taxation suggest that it should be fruitful to apply the basic insight that the effects of globalization are contingent on the position of the median to relevant areas of policy outcomes-particularly those relating to the welfare state. The model depends on parties losing credibility with the electorate if their policies are infeasible given the pressures of globalization. We have not attempted to test this mechanism in this study, partly because cross-national comparable data is difficult to find, but in reality the mechanism may be complex. Foreignexchange and financial markets may react only when they know what government is elected, so loss of electoral support may be delayed. If a coalition government forms, blame attribution may be even more indirect. Empirical work in this area using pooled data should prove fruitful, although serious issues arise because of the endogeneity of policy and market reaction and because of the way that the policies of nations affect each other. ${ }^{92}$

In sum, this study provides additional support for the literature on the contingent nature of the effects of globalization. Similar to findings in recent studies, a central implication is that pessimists have overstated the effects of globalization. Nevertheless, globalization does have an effect on parties' left-right positions, but the position of median voter mediates this effect. The central contribution of our study is to highlight the importance of the interaction between the position

${ }^{92}$ Bernhard and Leblang 2006. 
of the median voter and globalization. Clearly, the positions taken up by parties in electoral competition are not the only influence on government policy, but there is sufficient evidence to suggest that future empirical work on globalization needs to allow for the position of the median, which is still all too rare in the literature.

\section{REFERENCES}

Adams, James F., Michael Clark, Lawrence Ezrow, and Garrett Glasgow. 2004. "Understanding Change and Stability in Party Ideologies: Do Parties Respond to Public Opinion or to Past Election Results." British Journal of Political Science 34, no. 4: 589-611.

Adams, James F., Andrea Haupt, and Heather Stoll. 2009. "What Moves Parties? The Role of Public Opinion and Global Economic Conditions in Western Europe." Comparative Political Studies 42, no. 5: 611-39.

Adams, James F., Samuel Merrill III, and Bernard Grofman. 2005. A Unified Theory of Party Competition: A Cross-National Analysis Integrating Spatial and Behavioral Factors. Cambridge: Cambridge University Press.

Adams, James F., and Samuel Merrill III. 2006. "Why Small Centrist Third Parties Motivate Policy Divergence by Major Parties." American Political Science Review 100, no. 3: 403-17.

Adserà, Alicia, and Carles Boix. 2002. "Trade, Democracy, and the Size of the Public Sector: The Political Underpinnings of Openness." International Organization 56, no. 2: 229-62.

Allan, James P., and Lyle Scruggs. 2004. "Political Partisanship and Welfare State Reform in Advanced Industrial Societies." American Journal of Political Science 48, no. 3: 496-512.

Basinger, Scott J., and Mark Hallerberg. 2004. "Remodeling the Competition for Capital: How Domestic Politics Erases the Race to the Bottom." American Political Science Review 98, no. 2: 261-76.

Beck, Nathanial, and Jonathan N. Katz. 2004. "Time-Series-Cross-Section Issues: Dynamics, 2004.” Manuscript, New York University and California Institute of Technology.

Benoit, Kenneth, and Michael Laver. 2006. Party Policy and Modern Democracies. London: Routledge.

Bernhard, William, and David Leblang. 2006. "Polls and Pounds: Public Opinion and Exchange Rate Behavior in Britain." Quarterly Journal of Political Science 1, no. 1: 25-47.

Boix, Carles. 2000. "Partisan Governments, the International Economy, and Macro-economic Policies in Advanced Nations, 1960-1993." World Politics 53, no. 1: 38-73.

Brady, David, and Ryan Denniston. 2006. "Economic Globalization, Industrialization, and Deindustrialization in Affluent Democracies." Social Forces 85, no. 1: 297-327.

Brady, David, Martin Seeleib-Kaiser, and Jason Beckfield. 2005. "Economic Globalization and the Welfare State in Affluent Democracies, 1975-2001." American Sociological Review 70, no. 6: 921-48. 
Brams, Steven J., and Samuel Merrill III. 1983. "Equilibrium Strategies for FinalOffer Arbitration: There is No Median Convergence." Management Science 29, no. 8: 927-41.

Brooks, Sarah M. 2005. "Interdependent and Domestic Foundations of Policy Change: The Diffusion of Pension Privatization around the World." International Studies Quarterly 49, no. 2: 273-94.

Budge, Ian, Hans-Dieter Klingemann, Andrea Volkens, Judith Bara, and Eric Tanenbaum, eds. 2001. Mapping Policy Preferences: Estimates for Parties, Electors, and Governments 1945-1998. Oxford: Oxford University Press.

Burgoon, Brian. 2001. "Globalization and Welfare Compensation: Disentangling the Ties That Bind." International Organization 55, no. 3: 509-51.

Cai, Hongbin, and Daniel Triesman. 2005. "Does Competition for Capital Discipline Governments? Decentralization, Globalization, and Public Policy." American Economic Review 95, no. 3: 817-30.

Calvert, Randall. 1985. "Robustness of the Multidimensional Voting Model: Candidate Motivations, Uncertainty, and Convergence." American Journal of Political Science 29, no. 1: 69-95.

Cerny, Phillip G. 1990. The Changing Architecture of Politics. London: Sage.

Cox, Robert W. 1993. "Structural Issues of Global Governance: Implications for Europe.” In Stephen Gill, ed., Gramsci, Historical Materialism, and International Relations. Cambridge: Cambridge University Press: 259-89.

Dorussen, Han, and Kyriaki Nanou. 2006. "European Integration, Intergovernmental Bargaining, and Convergence of Party Programmes." European Union Politics 7, no. 2: 235-56.

Downs, Anthony. 1957. An Economic Theory of Democracy. New York: Harper.

Dreher, Axel. 2006. "Does Globalization Affect Growth: Evidence from a New Index of Globalization.” Applied Economics 38, no. 10: 1091-110.

Duggan, John, and Mark Fey. 2005. "Electoral Competition with Policy Motivated Candidates." Games and Economic Behavior 51, no. 4: 490-522.

Esping-Andersen, Gøsta. 1999. Social Foundations of Post-Industrial Democracies. Oxford: Oxford University Press.

Estevez-Abe, Margarita, Torben Iversen, and David Soskice. 2001. "Formation of Skills: A Reinterpretation of the Welfare State." In Peter A. Hall and David Soskice, eds., Varieties of Capitalism: The Institutional Foundations of Comparative Advantage. Oxford: Oxford University Press: 145-83.

European Commission. 2009. "Taxation Trends in the European Union: Data for the EU Member States and Norway." Manuscript, Luxembourg.

Financial Times. 2010. “Zapatero Finally Wields the Axe.” May 12: http:// cachef.ft.com/cms/s/0/8d2f8624-5dfa-11df-8153-00144feab49a.html\#axzz 1FuBlIEUp.

Garrett, Geoffrey. 1998. Partisan Politics in the Global Economy. Cambridge: Cambridge University Press.

Garrett, Geoffrey, and Deborah Mitchell. 2001. "Globalization, Government Spending, and Taxation in the OECD." European Journal of Political Research 39, no. 2: $145-78$.

Green, Duncan, and Maurice Griffith. 2002. "Globalization and its Discontents." International Affairs 78, no. 1: 49-68.

Guardian. 2006. “Gordon Brown's Mansion House Speech.” June 22: http://www .guardian.co.uk/business/2006/jun/22/politics.economicpolicy. 
Ha, Eunyoung. 2008. "Globalization, Veto Players, and Welfare Spending." Comparative Political Studies 41, no. 6: 783-813.

Hall, Peter, and Daniel W. Gingerich. 2009. "Varieties of Capitalism and Institutional Complementarities in the Political Economy: An Empirical Analysis." British Journal of Political Science 39, no. 4: 449-82.

Hall, Peter A., and David Soskice. 2001. "An Introduction to Varieties of Capitalism." In Peter A. Hall and David Soskice, eds., Varieties of Capitalism: The Institutional Foundations of Comparative Advantage. Oxford: Oxford University Press: 1-70.

Hall, Peter, and Kathleen Thelen. 2009. "Institutional Change in Varieties of Capitalism." In Bob Hancké, ed., Debating Varieties of Capitalism. Oxford: Oxford University Press: 251-72.

Haupt, Andrea B. 2010. "Parties' Responses to Economic Globalization: What is Left for the Left and Right for the Right?” Party Politics 16, no. 1: 5-27.

Hays, Jude C., 2003. "Globalization and Capital Taxation in Consensus and Majoritarian Democracies.” World Politics 56, no. 1: 79-113.

Hearl, Derek J. 2001. "Checking the Party Policy Estimates: Reliability.” In Ian Budge, Hans-Dieter Klingemann, Andrea Volkens, Judith Bara, and Eric Tanenbaum, eds. 2001. Mapping Policy Preferences: Estimates for Parties, Electors, and Governments 1945-1998. Oxford: Oxford University Press, 111-26.

Held, David, Anthony McGrew, David Goldblatt, and Jonathan Perraton. 1999. Global Transformations. Cambridge: Polity Press.

Hellwig, Timothy T. 2001. "Interdependence, Government Constraints, and Economic Voting." Journal of Politics 63, no. 4: 1141-162.

- Forthcoming. "Globalization, Policy Constraints, and Vote Choice." Journal of Politics.

Heshmati, Almas. 2006. "Measurement of a Multidimensional Index of Globalization." Global Economy Journal 6, no. 2: 1-28.

Hibbs, Douglas A. 1987. The Political Economy of Industrial Democracies. Cambridge Mass.: Harvard University Press.

Huber, John. 1989. "Values and Partisanship in Left-Right Orientation: Measuring Ideology." European Journal of Political Research 17, no. 5: 599-621.

Iversen, Torben, and Thomas R. Cusack. 2000. "The Causes of Welfare State Expansion: Deindustrialization of Globalization?" World Politics 52, no. 3: 313-49.

Iversen, Torben, and David Soskice. 2006. "Electoral Institutions, Parties, and the Politics of Class: Why Some Democracies Distribute More than Others." American Political Science Review 100, no. 2: 165-81.

- 2009. "Distribution and Redistribution: The Shadow of the Nineteenth Century," World Politics 61, no. 3: 438-86.

Kearney, A. T., and Foreign Policy. 2006. "The Globalization Index.” Foreign Policy, November/December: 75-81.

Keefer, Phillip. 2005. "DPI2004 Database of Political Institutions: Changes and Variable Definitions.” Manuscript, World Bank.

Kenworthy, Lane. 2003. "Quantitative Indicators of Corporatism.” International Journal of Sociology 33, no. 3: 10-44.

- 2006. "Institutional Coherence and Macroeconomic Performance." Socio-Economic Review 4, no. 1: 69-91. 
Kim, Heemin, and Richard C. Fording. 2003. "Voter Ideology in Western Democracies: An Update." European Journal of Political Research 42, no. 1: 95-105.

Kitschelt, Herbert P. 2001. "Partisan Competition and Welfare State Retrenchment: When Do Politicians Choose Unpopular Policies?” In Paul Pierson, ed., The New Politics of the Welfare State. Oxford: Oxford University Press: 265302.

Klingemann, Hans-Dieter, Andrea Volkens, Judith Bara, Ian Budge, and Michael McDonald. 2006. Mapping Policy Preferences II: Estimates for Parties, Electors and Governments in Central and Eastern Europe, European Union, and OECD 1990-2003. Oxford: Oxford University Press.

Laver, Michael, Kenneth Benoit, and John Garry. 2003. "Extracting Policy Positions from Political Texts Using Words as Data." American Political Science Review 97, no. 2: 311-31.

Lijphart, Arendt. 1999. Patterns of Democracy: Government Forms and Performance in Thirty-Six Countries. New Haven: Yale University Press.

Lockwood, Ben. 2004. "How Robust is the Foreign Policy-Kearney Globalization Index?” The World Economy 27, no. 4: 507-23.

Marks, Gary, ed. 2007. "Special Symposium: Comparing Measures of Party Positioning: Expert, Manifesto, and Survey Data.” Electoral Studies 26: 1-141.

McDonald, Michael D., and Ian Budge. 2005. Elections, Parties, Democracy: Conferring the Median Mandate. Oxford: Oxford University Press.

McDonald, Michael D., and Silvia M. Mendes. 2001. "Checking the Party Policy Estimates: Convergent Validity." In Ian Budge, Hans-Dieter Klingemann, Andrea Volkens, Judith Bara, and Eric Tanenbaum, eds., Mapping Policy Preferences: Estimates for Parties, Electors and Governments 1945-1998. Oxford: Oxford University Press: 127-42.

Milner, Helen V., and Benjamin Judkins. 2004. "Partisanship, Trade Policy, and Globalization: Is There a Left-Right Divide on Trade Policy?” International Studies Quarterly 48, no. 1: 95-119.

Nanou, Kyriaki. 2009. "European Integration and Electoral Democracy: How the EU Constrains Party Competition in its Member States.” Ph.D. diss., University of Essex.

Nelson, Stephen, and Christopher Way. 2007. "Party Crashers: The Determinants of Left Party Ideological Shifts in Wealthy Democracies." Paper presented at the annual meeting of the Midwest Political Science Association, Chicago, April 12-15.

Oatley, Thomas. 1999. "How Constraining Is Capital Mobility? The Partisan Hypothesis in an Open Economy." American Journal of Political Science 43, no. 4: 1003-27.

Pierson, Christopher. 2006. Beyond the Welfare State: The New Political Economy of Welfare. Cambridge: Polity.

Plümper, Thomas, and Vera E. Troeger. 2007. "Efficient Estimation of TimeInvariant and Rarely Changing Variables in Finite Sample Panel Analysis with Unit Fixed Effects." Political Analysis 15, no. 1: 124-39.

Pontusson, Jonas G. Forthcoming. "Once Again a Model: Nordic Social Democracy in a Globalized World.” In James Cronin, George Ross, and James Shoch, eds., Futures of the Left. Durham, N.C.: Duke University Press.

Pontusson, Jonas, and David Rueda. 2010. "The Politics of Inequality: Voter Mo- 
bilization and Left Parties in Advanced Industrial States." Comparative Political Studies 43, no. 6: 675-705.

Potrafke, Niklas. 2009. "Did Globalization Restrict Partisan Politics? An Empirical Evaluation of Social Expenditures in a Panel of OECD Countries." Public Choice 140, no. 1-2: 105-24.

Quinn, Dennis P., and A. Maria Toyoda. 2008. "Ideology and Voter Preferences as Determinants of Financial Globalization.” American Journal of Political Science 51, no. 2: 344-63.

Rodrik, Dani. 1997. Has Globalization Gone Too Far? Washington, D.C.: Institute for International Economics.

Roemer, John E. 2001. Political Competition: Theory and Application. Cambridge: Harvard University Press.

Rogowski, Ronald. 2003. "International Capital Mobility and National Policy Divergence." In Miles Kahler and David A. Lake, eds., Governance in a Global Economy. Princeton: Princeton University Press, 255-74.

Scharpf, Fritz W. 1998. "The Limitations on State Capacity." Swiss Political Science Review 4, no. 1: 2-8.

Schmitt, Herman, and Evi Scholz. 2005. The Mannheim Eurobarometer Trend File, 1970-2002. Ann Arbor, Mich.: Inter-university Consortium for Political and Social Research.

Simon, Herbert A. 1985. "Human Nature in Politics: The Dialogue of Psychology with Political Science." American Political Science Review 79, no. 2: 293-304.

Stock, James H., and Mark W. Watson. 2006. "Heteroskedasticity-Robust Standard Errors for Fixed Effects Panel Data Regression.” National Bureau of Economic Research Technical Working Paper 323. Cambridge, Mass.: National Bureau of Economic Research, Inc.

Swank, Duane. 2005. "Globalization, Domestic Politics, and Welfare State Retrenchment in Capitalist Democracies." Social Policy and Society 4, no. 2: 18395.

Swank, Duane, and Sven Steinmo. 2002. "The New Political Economy of Taxation in Advanced Capitalist Democracies." American Journal of Political Science 46, no. 3: 642-55.

Taylor, Mark Z. 2009. "Empirical Evidence against Varieties of Capitalism's Theory of Technological Innovation.” In Bob Hancké, ed., Debating Varieties of Capitalism. Oxford: Oxford University Press: 221-50.

Van Kersbergen, Kees. 2000. "The Declining Resistance of Welfare States to Change." In Stein Kuhnle, ed., Survival of the European Welfare State. Routledge: London, 19-41.

Venn, Danielle. 2009. "Legislation, Collective Bargaining and Enforcement: Updating the OECD Employment Protection Indicators." Organization of Economic Cooperation and Development Working Papers, at www.oecd.org/els/ workingpapers. Accessed January 11, 2011.

Vogel, David. 1995. Trading Up: Consumer and Environmental Regulation in a Global Economy. Cambridge: Harvard University Press.

Warwick University Center for the Study of Globalization. The CSGR Globalization Index, at www2.warwick.ac.uk/fac/soc/csgr/index. Accessed April 14, 2008. 
Wittman, Donald. 1983. "Candidate Motivation: A Synthesis of Alternative Theories." American Political Science Review 77, no. 1: 142-57.

Wooldridge, Jeffrey M. 2006. Introductory Econometrics: A Modern Approach, 3rd ed. Mason, Ohio: South-Western. 